\title{
ॠUSGS
}

science for a changing world

\section{The Geologic Story of Colorado's Sangre de Cristo Range}

Circular 1349

$x^{2} \times 2$

U.S. Departiment of the Interior U.S. Geological Survey
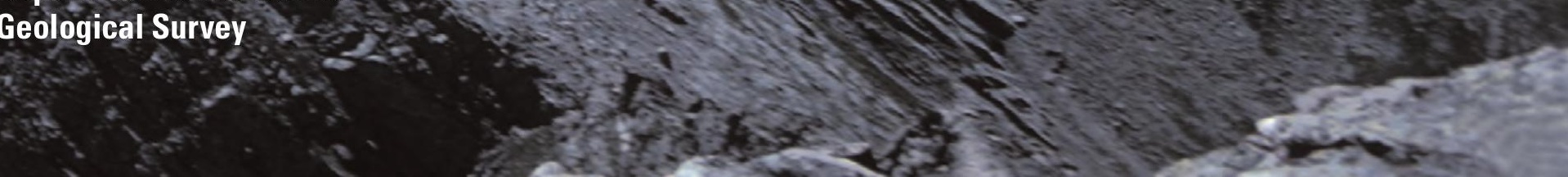
Cover shows a landscape carved by glaciers. Front cover, Crestone Peak on left and the three summits of Kit Carson Mountain on right. Back cover, Humboldt Peak on left and Crestone Needle on right. Photograph by the author looking south from Mt. Adams. 


\section{The Geologic Story of Colorado's Sangre de Cristo Range}

By David A. Lindsey

A description of the rocks and landscapes of the Sangre de Cristo Range and the forces that formed them.

Circular 1349 


\section{U.S. Department of the Interior KEN SALAZAR, Secretary \\ U.S. Geological Survey Marcia K. McNutt, Director}

\section{U.S. Geological Survey, Reston, Virginia: 2010}

This and other USGS information products are available at http://store.usgs.gov/ U.S. Geological Survey

Box 25286, Denver Federal Center

Denver, CO 80225

To learn about the USGS and its information products visit http://www.usgs.gov/ 1-888-ASK-USGS

Any use of trade, product, or firm names is for descriptive purposes only and does not imply endorsement by the U.S. Government.

Although this report is in the public domain, permission must be secured from the individual copyright owners to reproduce any copyrighted materials contained within this report.

Suggested citation:

Lindsey, D.A., 2010, The geologic story of Colorado's Sangre de Cristo Range: U.S. Geological Survey Circular 1349, $14 \mathrm{p}$. 


\section{Contents}

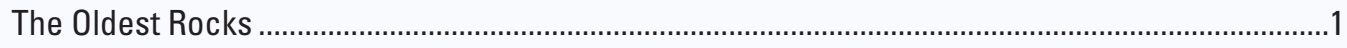

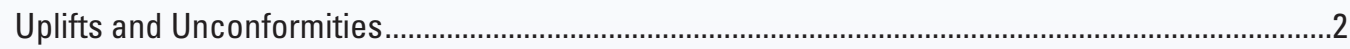

A Map of the Range .......................................................................................................

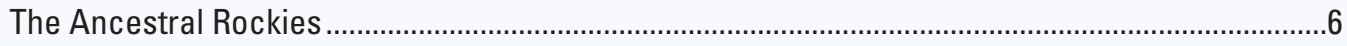

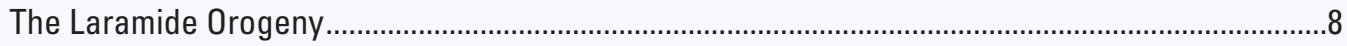

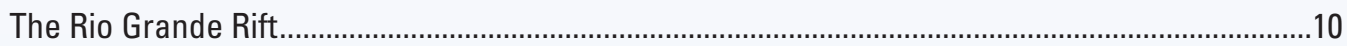

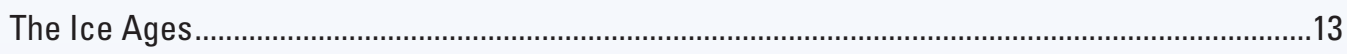

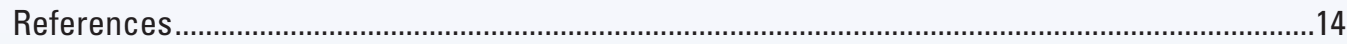

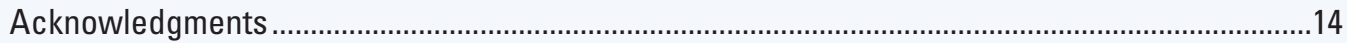

\section{Figures}

1. Precambrian rocks south of Crestone: (A) layered gneiss; (B) pink granite;

(C) dark igneous rock (gabbro) with granitic veins

2. Uplifts and unconformities. Rocks of early Paleozoic age lap onto an old highland to the south and were partly dissolved and eroded before rocks of late Paleozoic age were deposited.

3. Geologic map of Colorado's Sangre de Cristo Range......................................................

4. The Ancestral Rockies. Map and photographs of Crestone Conglomerate .......................6

5. At Marble Mountain, fossil mounds called bioherms in limestone of the Minturn Formation have been thrust over the younger Sangre de Cristo Formation along the Marble Mountain thrust fault.

6. A redbed under the microscope, showing iron oxide ......................................................

7. The Laramide orogeny. Photographs of folded and faulted rocks of Pennsylvanian and Permian age and section showing structure....

8. The Rio Grande rift. Map and photographs of the Sangre de Cristo fault in the San Luis Valley

9. The ice ages. Aspen cover a lateral moraine in Black Canyon, north of Valley View Hot Springs 


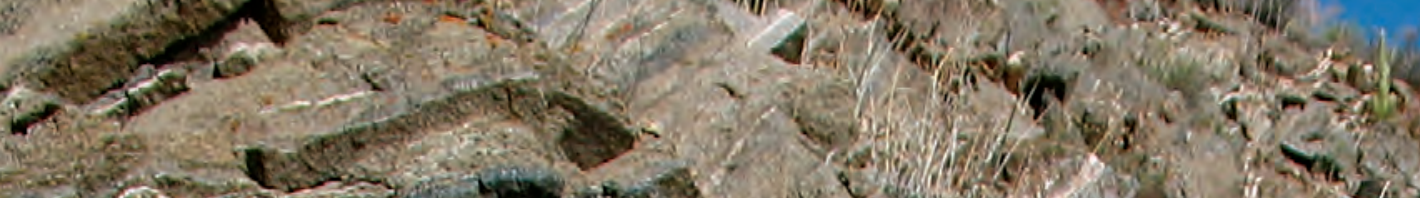
$-2 x-3$ trita 4

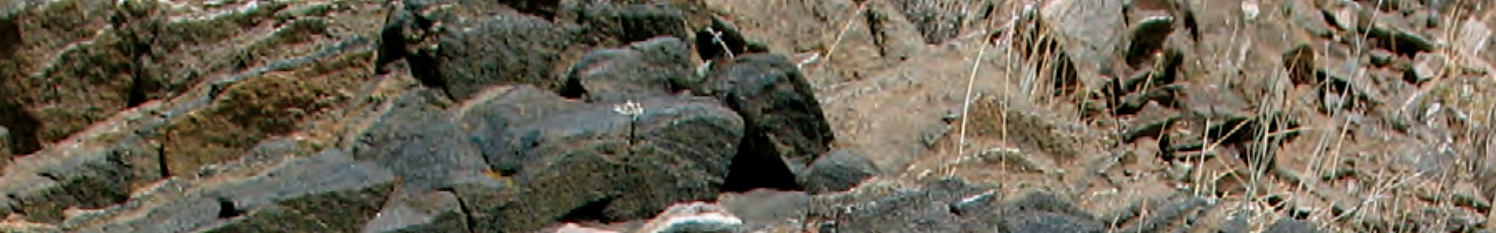

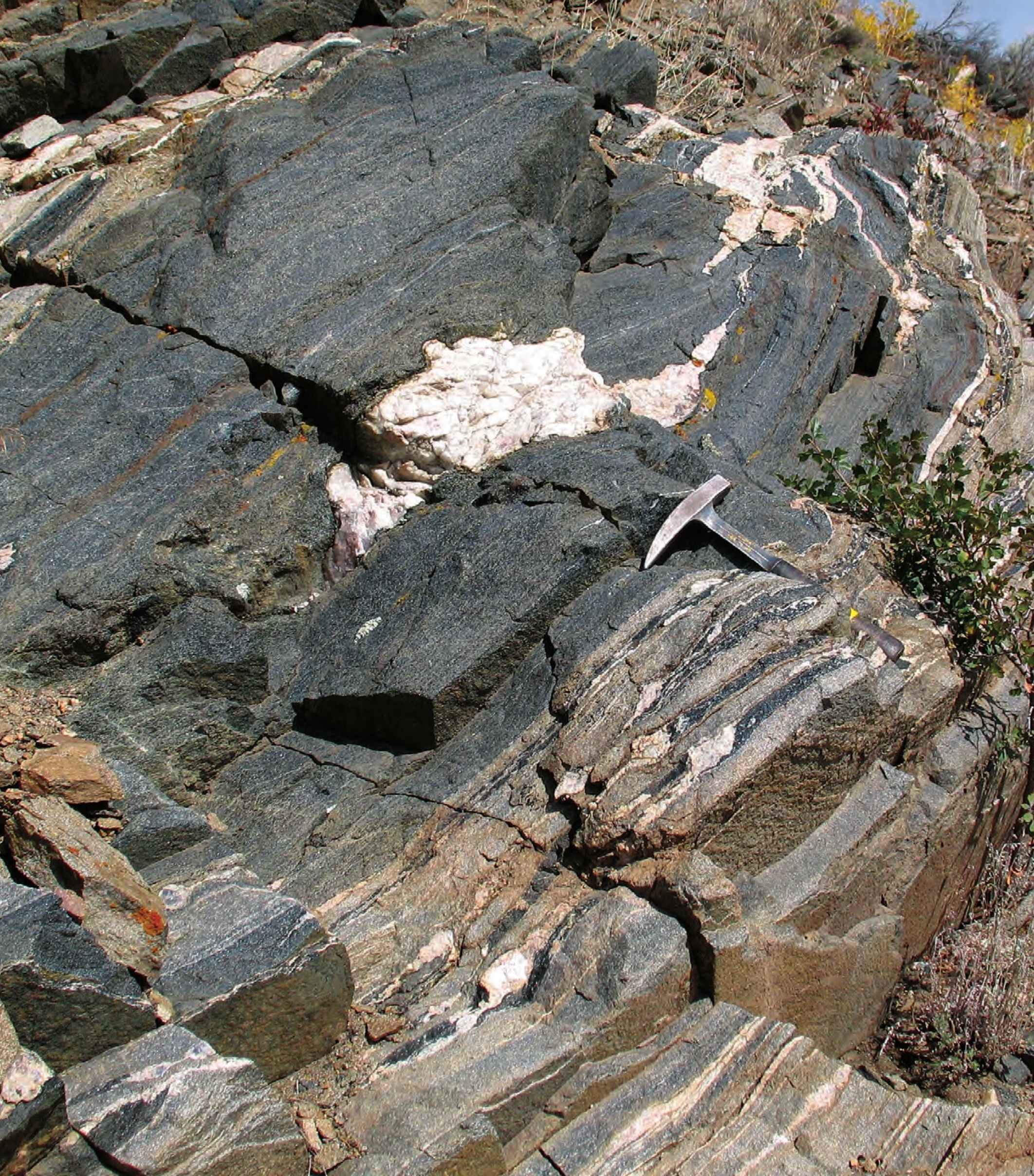


with this old continent. Sea-floor plates usually are heavier than continents and are swept beneath them (a process called "subduction"). However, some plate fragments are torn away and plastered against the continent-this is how continents grow. Rocks in the subducted plate melt and plumes of molten rock rise through the newly enlarged continent, solidifying below the surface as plutons or erupting as volcanoes. Today the results of this process of ancient continental growth are exposed as gneiss and granite in mountain uplifts like the Sangre de Cristo Range.

\section{Uplifts and Unconformities}

At many places in the world, including the Sangre de Cristo Range, a great gap in time separates younger rocks from those of Precambrian age. We recognize time gaps where rock layers that should be present—because they are seen elsewhere-are missing. Geologists call these horizons of missing rocks "unconformities." Unconformities are important to understanding Earth history; they are strong evidence for uplift and erosion (see fig. 2).

If you look up the valleys on the west side of the range from Crestone north, you will see large cliffs of gray Mississippian age limestone- this is the Leadville Limestone, deposited from about 360 to 326 million years ago. The Leadville Limestone is underlain by less obvious, thinner formations of dolomite and sandstone of Ordovician and Devonian age, deposited between 490 and 360 million years ago. At the bottom of this sequence are the Ordovician formations, oldest to youngest: the
Manitou Dolomite, Harding Sandstone, and Fremont Dolomite, and the Devonian Chaffee Formation (dolomite and sandstone). At different places, both the Manitou and Harding lie unconformably on Precambrian rocks. This unconformity represents 1 billion years of Earth history missing from the Sangre de Cristo Range; all of the evidence for this history is gone. Whatever rocks formed in this place, whether igneous or sedimentary, were removed by erosion before the Ordovician seas covered it. By Ordovician time, a broad highland stood above the Ordovician sea over what is now southern Colorado. The Ordovician sea slowly encroached on the uplift, producing an onlapping sequence of successively younger formations. By Mississippian time, when the Leadville Limestone was deposited, the sea probably covered the entire highland. In fact, we find marine limestone of this age throughout the Rocky Mountains.

Then sea level fell, and a second unconformity began to form. Land displaced shallow seas; rocks were exposed to weathering and erosion. In the warm, humid climate, limestone dissolved; caves and caverns formed. The Leadville Limestone collapsed to form a jumble of sharp rock fragments we call "karst," a German name for a region in Slovenia, where water has dissolved much of the landscape. Weathering and erosion stripped Paleozoic rocks from a wide area of southern Colorado. No rocks of Ordovician to Mississippian age are found in the Sangre de Cristo Mountains south of the Great Sand Dunes. On the highland, the two unconformities merge into one, indivisible break in the rock record. To the south (for example, where highway 160 crosses the mountains at La Veta Pass), rocks of Pennsylvanian age, deposited about 320-300 million years ago, lie directly on Precambrian rocks. 


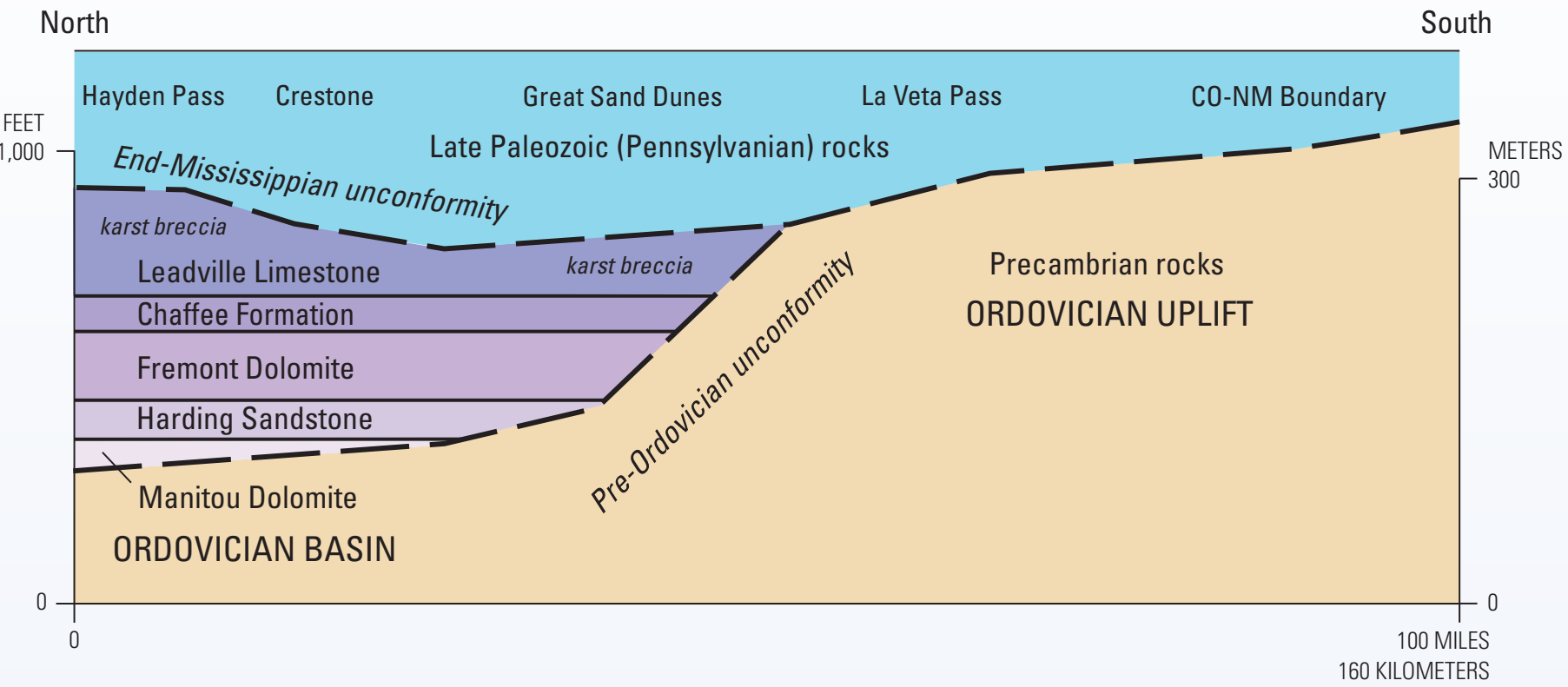

Figure 2. Uplifts and unconformities. Rocks of early Paleozoic age lap onto an old highland to the south and were partly dissolved and eroded before rocks of late Paleozoic age were deposited. 


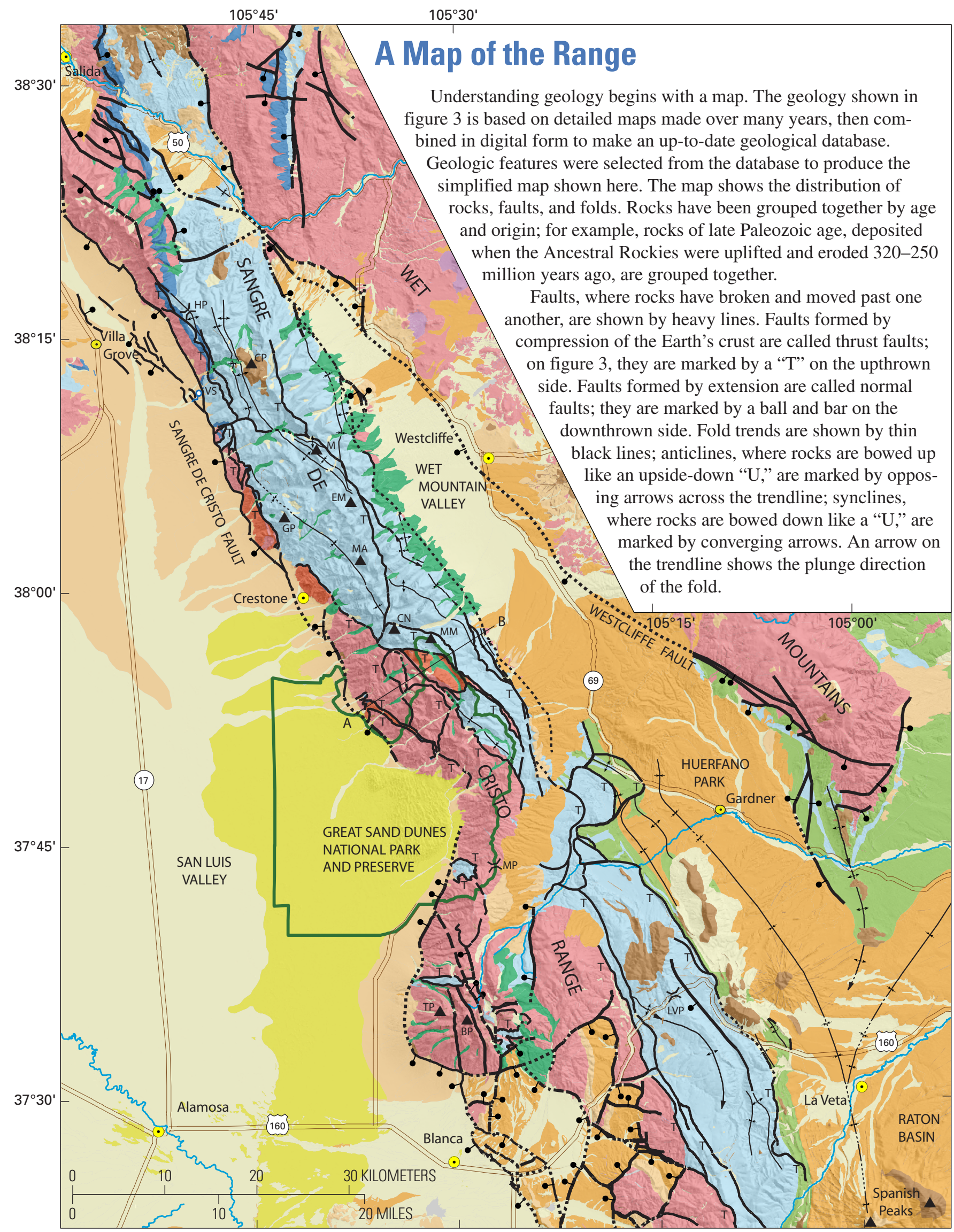

Map compiled by T. Klein, E. DeWitt, and C. San Juan, U.S. Geological Survey. 


\section{EXPLANATION}

Quaternary

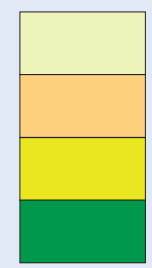

Alluvium

Alluvial fans

Windblown sand

Glacial deposits

Tertiary

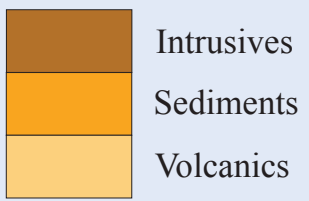

Mesozoic

Sedimentary rocks

Paleozoic sedimentary rocks

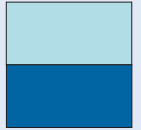

Late Paleozoic

Early Paleozoic

Late Precambrian and early Paleozoic Intrusives in Wet Mountains

Precambrian

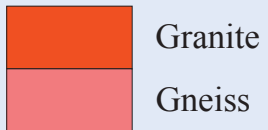

๑ ".... Normal fault, ball and bar on downthrown side

T..... Thrust or reverse fault, "T" on upper plate, dotted where concealed

$\downarrow$ Anticline, arrow shows direction of plunge

Syncline, arrow shows direction of plunge

\section{CORRELATION OF MAP UNITS AND GEOLOGIC HISTORY}

Ice ages: glaciers carve the present mountains MILLIONS OF YEARS / Rio Grande rift: Sangre de Cristo

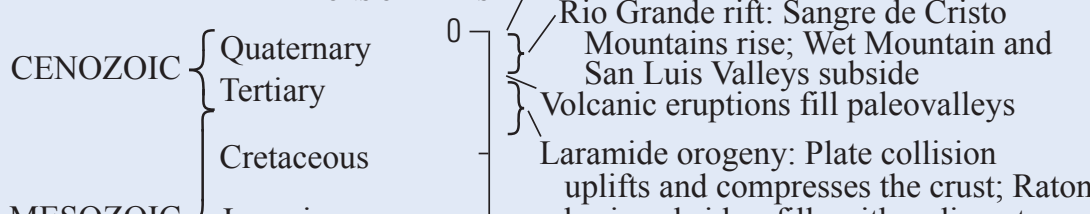
basin subsides, fills with sediment
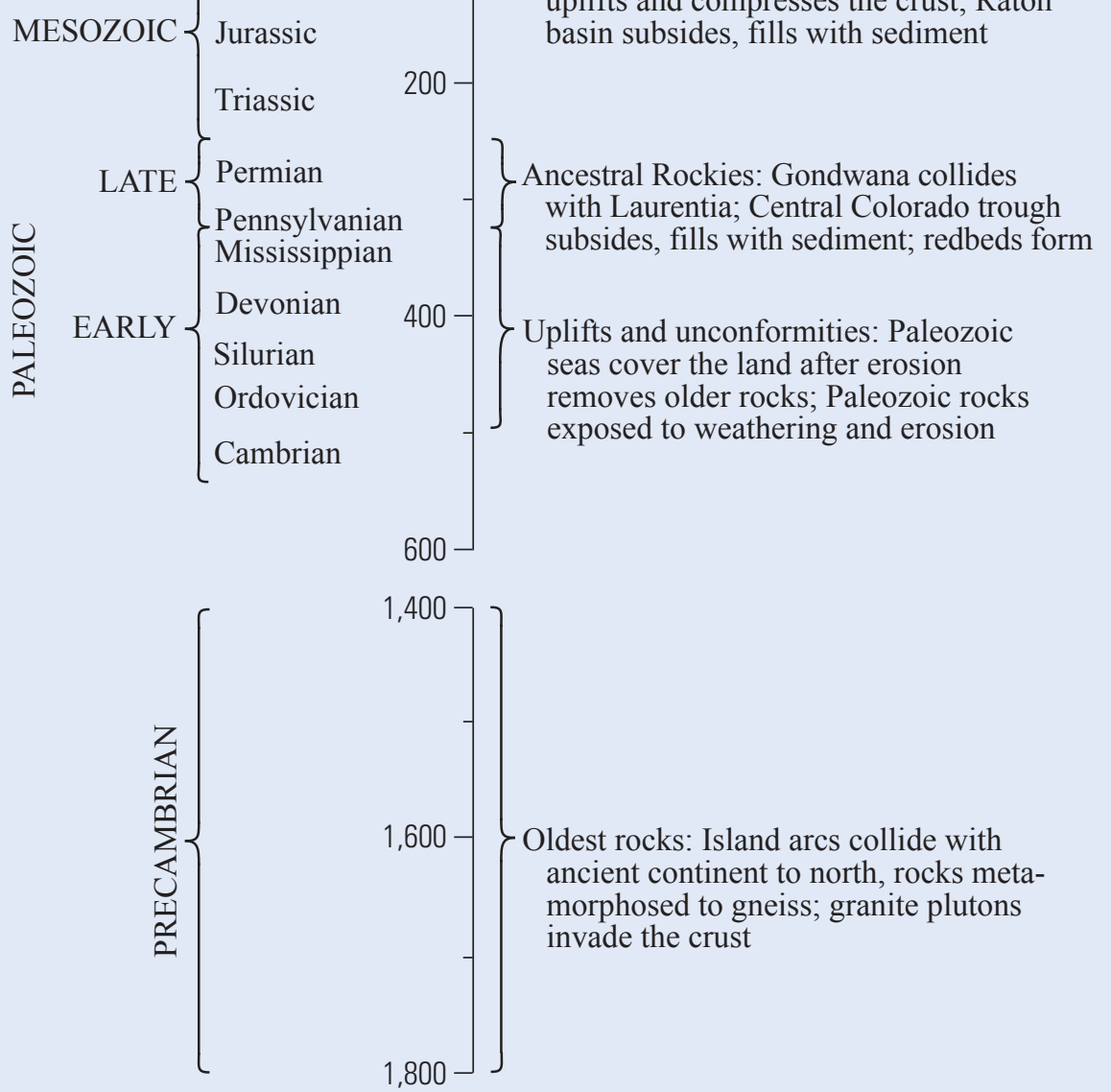

Oldest rocks: Island arcs collide with ancient continent to north, rocks metamorphosed to gneiss; granite plutons invade the crust

Figure 3 (pages 4 and 5). Geologic map of Colorado's Sangre de Cristo Range. BP, Blanca Peak; CP, Cottonwood Peak; CN, Crestone Needle; EM, Eureka Mountain; GP, Gibson Peak; HP, Hayden Pass; LVP, La Veta Pass; M, Mt. Marcy; MA, Mt. Adams; MM, Marble Mountain; MP, Mosca Pass; TP, Twin Peaks; VS, Valley View Hot Springs. 


\section{The Ancestral Rockies}

The first Rocky Mountains, called the "Ancestral Rockies," began to rise about 320 million years ago during Pennsylvanian time (fig. 4A). Like the present Rocky Mountains, deep fault-bounded basins separated individual ranges of the Ancestral Rockies but, unlike the present Rockies, these basins were filled with shallow seas. Geologists continue to speculate about how the Ancestral Rockies formed, whether by compression and thrusting of the crust or by strike-slip faulting, or some combination of these, perhaps when two large ancient continents, Laurentia (North America and Europe combined) and Gondwana (South America and Africa combined) collided.

However they formed, the Ancestral Rockies were largely worn down by erosion by the end of Permian time, about 250 million years ago. West of the present Sangre de Cristo Range, an uplift called the Uncompahgre highland shed silt, sand, and coarse gravel (figs. 4B, C, D) into a basin called the central Colorado trough. The sedimentary fill of the trough is exposed throughout central Colorado today. In the Sangre de Cristo Range, north of the Great Sand Dunes, the sedimentary fill reached more than 2 miles thick. Geologists divide this fill into the Pennsylvanian Minturn and the Pennsylvanian and Permian Sangre de Cristo Formations; today it makes up most of the backbone of the range. The Crestone Conglomerate Member of the Sangre de Cristo Formation, which makes up Crestone Needle and many peaks in the central part of the range, was deposited nearest the uplift. It is so coarse that it contains boulders as much as 6 feet in diameter.

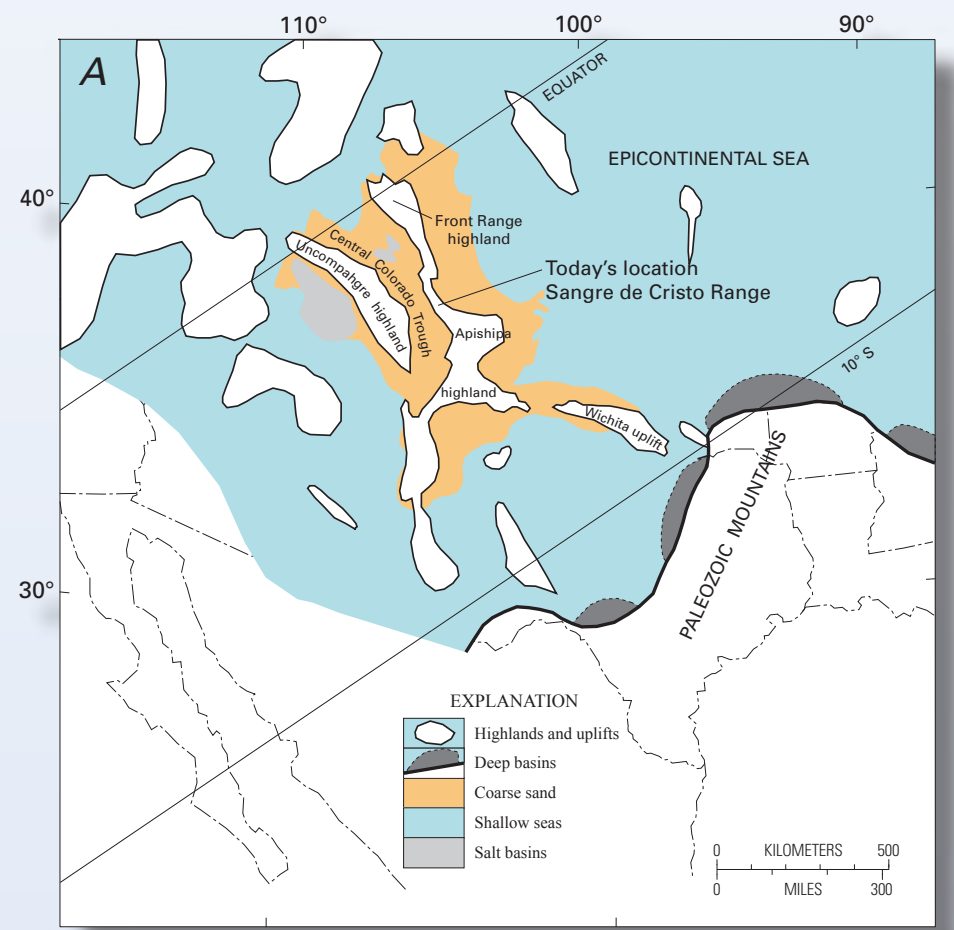

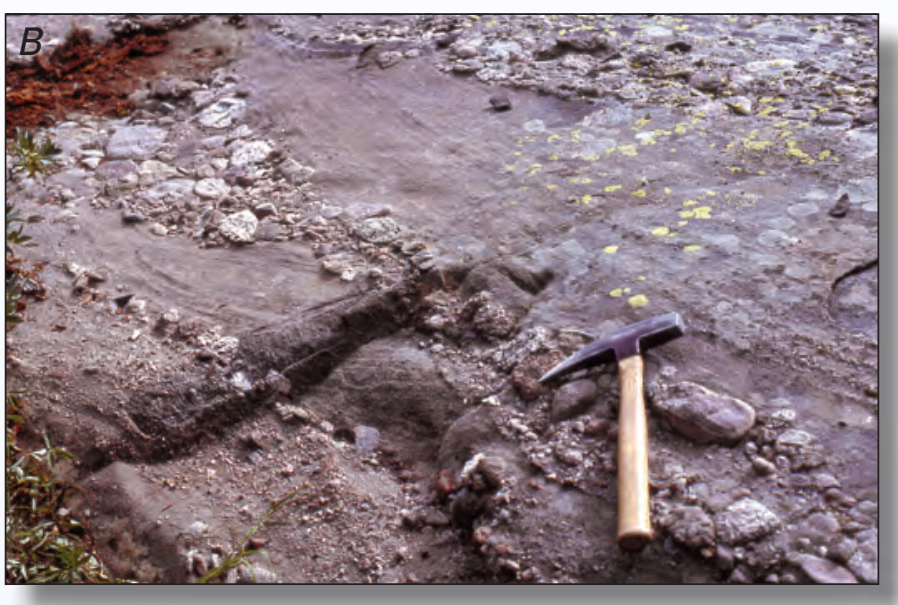

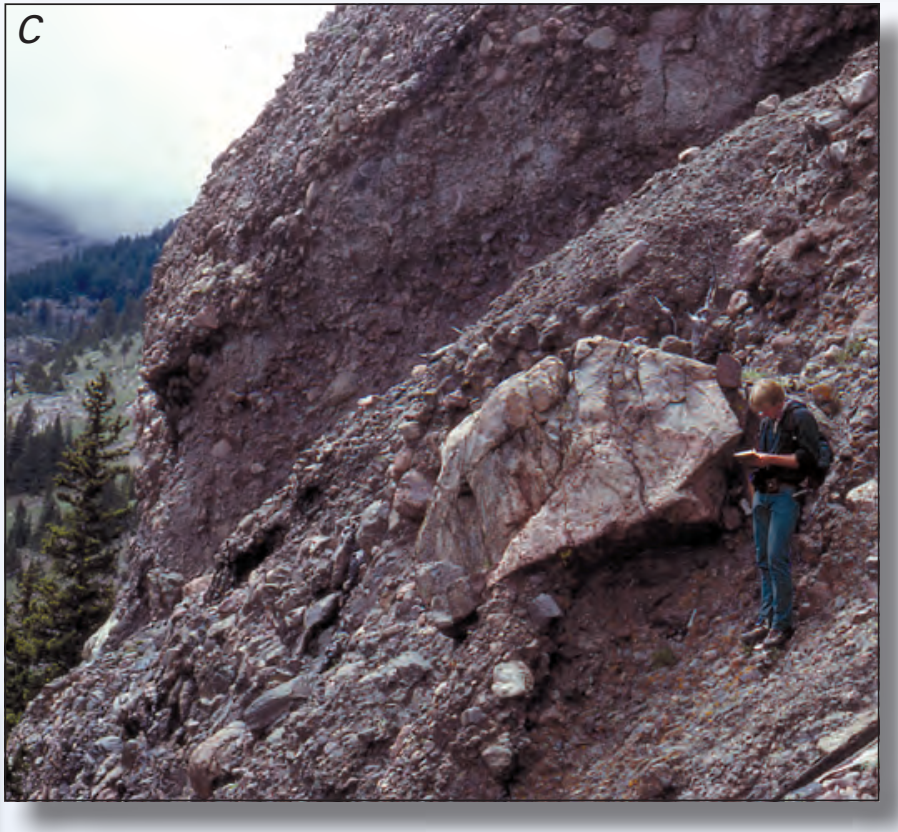

Figure 4 (pages 6 and 7). The Ancestral Rockies. (A) A map of the Western United States, showing the Ancestral Rocky Mountains about 300 million years ago. From Lindsey and others, 1986. Colorado was near the equator at that time; however, it is shown at its present position. Deposits in the Crestone Conglomerate, formed by erosion of the Ancestral Rockies: $(B)$ stream-rounded pebbles and structures formed by flowing water in sandstone (pick 12 inches in length for scale); $(C)$ cobbles and boulders in poorly sorted debris flows; and $(D)$ mudflows (top half of picture) and stream deposits (bottom half) in cliffs southwest of Eureka Mountain. 


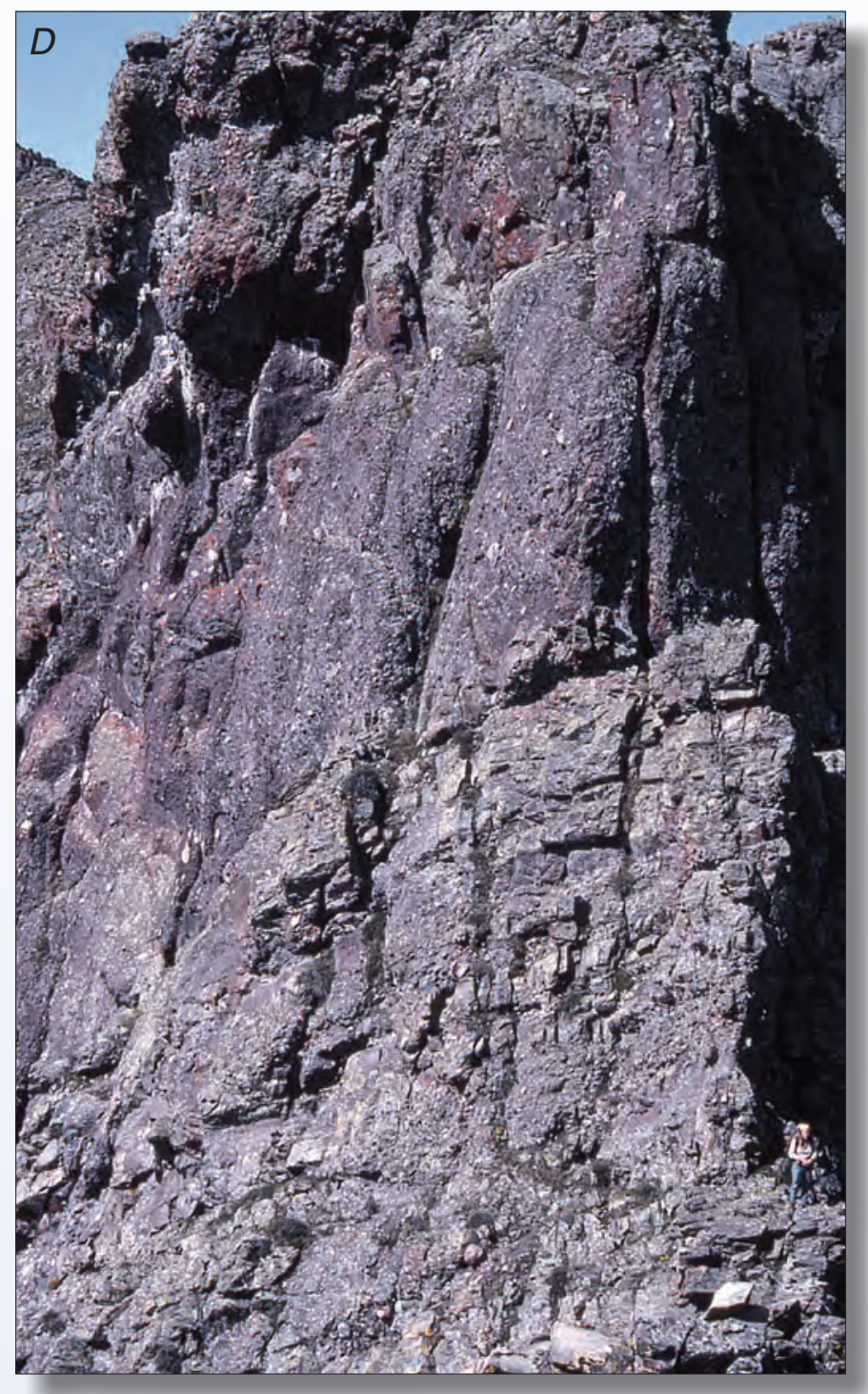

The Minturn Formation contains cyclic sequences of sedimentary rocks that record the rise and fall of sea level along a coastline dominated by river deltas. These cycles are thought to reflect the growth and retreat of glaciers on the great southern continent, Gondwana, during Pennsylvanian time. When the glaciers of Gondwana melted, sea level rose and limestone with marine fossils was deposited in warm, shallow seas. When the glaciers grew, sea level fell and rivers covered the former sea bottom with coarse sand. Land plants, such as ferns and even small trees, grew in swamps along the coast. The best place to see these sea-level cycles and their fossils is in valleys on the east side of the range.

At a few places on the shallow seafloor, invertebrate marine animals, such as crinoids, brachiopods, and coral—and also algae-were so numerous that their remains form mounds called bioherms hundreds of feet thick. Fragmental textures and coarse calcite in cavities show that the bioherms were partly dissolved and re-cemented while they grew, probably as they were alternately exposed and submerged at sea level. The best place to see the bioherms is Marble Mountain, on the east side of the range (fig. 5).

When the Uncompahgre highland rose quickly, coarse sand, pebbles and even boulders overwhelmed the shallow seas around it. Near the highland, floods and debris flows swept out of steep canyons and spread coarse gravel onto alluvial plains. Sediment accumulated rapidly, and the basins around the Ancestral Rockies sank miles deep.

Figure 5. At Marble Mountain, fossil mounds called bioherms (B) in limestone of the Minturn Formation $(\mathbb{P m})$ have been thrust over the younger Sangre de Cristo Formation (PPs) along the Marble Mountain thrust fault (MMT).

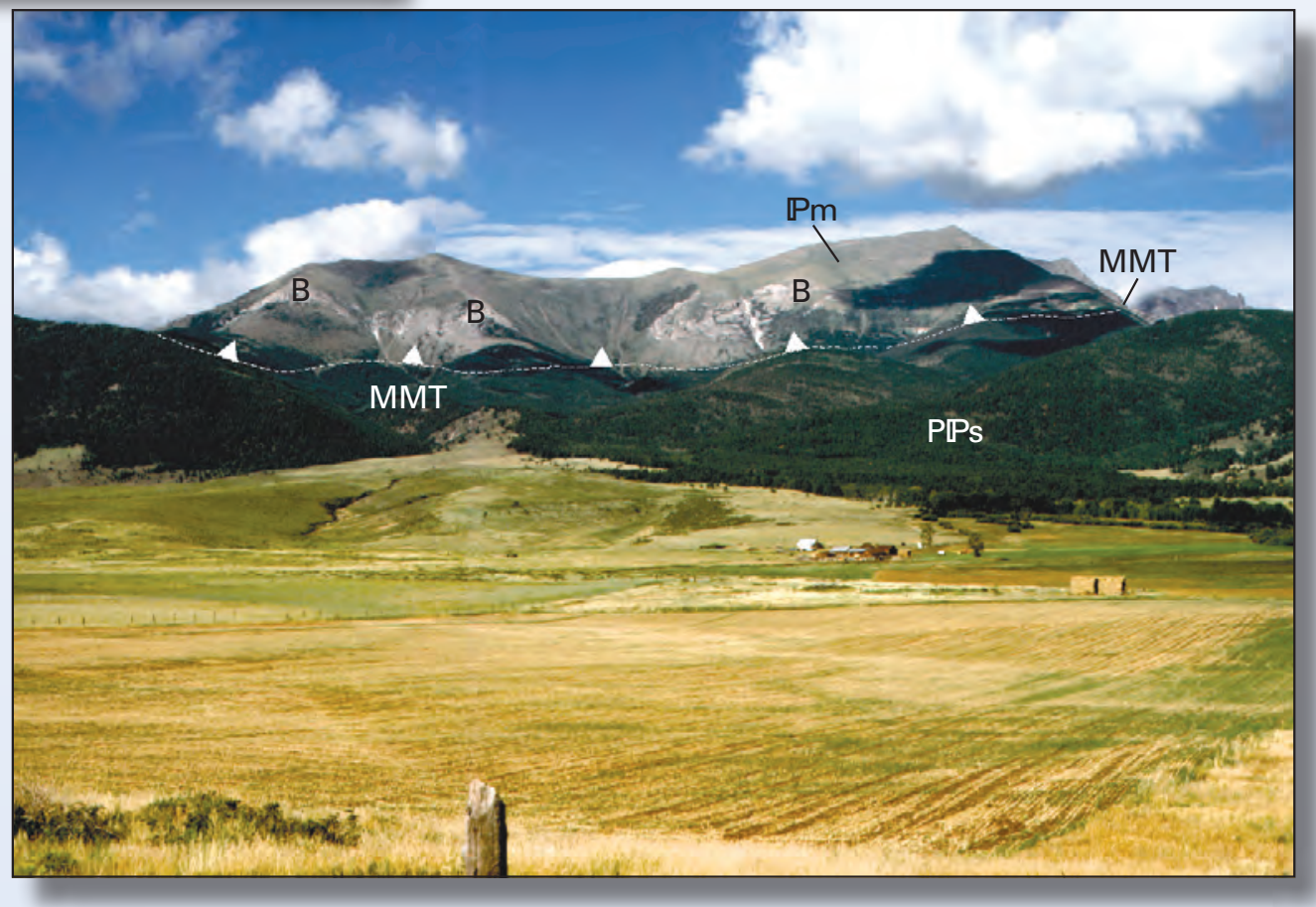


All around the flanks of the Ancestral Rockies, groundwater entered the newly deposited basin sediments. These sediments were not composed of pure quartz, but of unaltered, chemically unstable grains of feldspar and iron and magnesium minerals, such as hornblende and biotite. As soon as oxidizing groundwater began to react with these unstable minerals, iron began to move out of the minerals and into adjacent pore spaces, where it formed an insoluble gel of iron oxide (fig. 6). This gel gradually crystallized to the red iron oxide mineral, hematite. Today, this hematite gives the rocks their red color that imparts a red-pink glow to the mountains (especially at sunrise and sunset). Perhaps it was the red hematite that inspired $18^{\text {th }}$ century Spanish explorers to name the mountains "Sangre de Cristo" (Blood of Christ).*

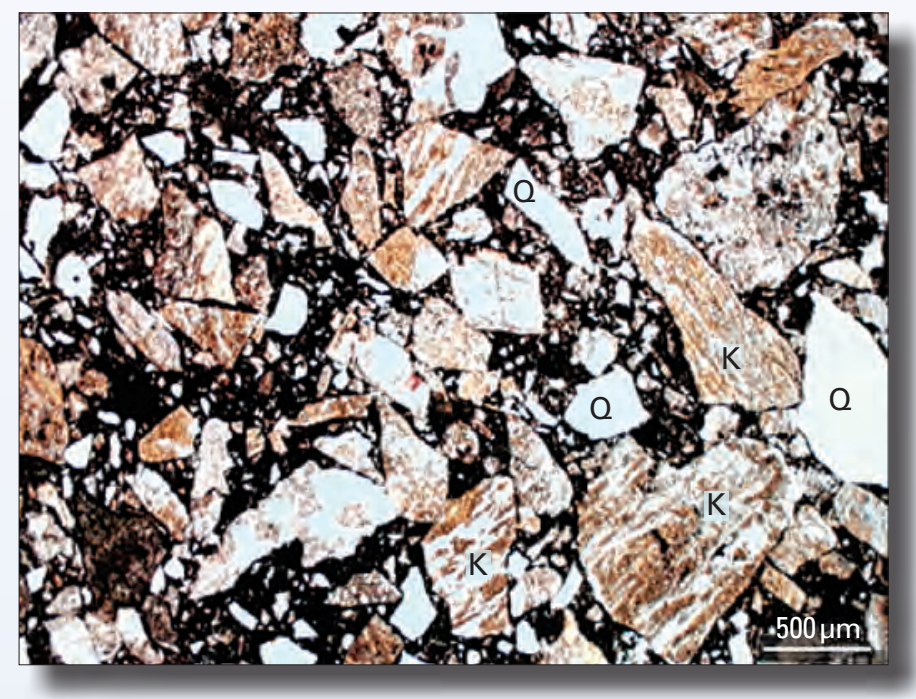

Figure 6. A redbed under the microscope, showing iron oxide (black) in pores between sand-size grains of feldspar ( $\mathrm{K}$, stained orange for identification) and quartz $(0$, clear); scale is 500 micrometers (1 micrometer $=1 / 1,000$ millimeter $)$, lower right. Although iron oxide imparts a red color to the rock, it appears black under the microscope because it is opaque in light shined through a thin section from below.

\section{The Laramide Orogeny}

"Laramide orogeny" is the name given to the processes that formed the Rocky Mountains about 80 to 40 million years ago, during Late Cretaceous and early Tertiary time. Faults and folds (figs. 7A, B) of the Laramide orogeny-some are large enough to show on the map in figure 3-can be seen throughout the Sangre de Cristo Range. They were formed by compression and uplift when tectonic plates beneath the North Pacific Ocean were forced (subducted) under the lighter continental crust of the western North American plate. Where the continental crust was thin, west of a line that passes through western Montana, Wyoming, and Utah, the eastward motion of subducting crust produced a broad north-south belt of lowangle faults (overthrusts). East of the overthrust belt, in the Rocky Mountain interior of North America, where the crust was thick, large fault-bounded uplifts and basins formed.

In Colorado, the old Uncompahgre and Front Range highlands of the Ancestral Rockies were uplifted again. However, the present site of the Sangre de Cristo Range was not one of these highlands. At the beginning of the Laramide orogeny, a shallow sea extended west over the area of the present Sangre de Cristo Range. A now-vanished uplift, sometimes called the Laramide San Luis highland, rose to the west of the present San Luis Valley. The San Luis highland may have connected to the Laramide Uncompahgre highland to the northwest, forming a single large uplift across southwestern Colorado.

Commonly, deep-rooted, high-angle reverse faults surround such interior uplifts on one or more sides. Less often, compression of highland against basin fill produces a stack of low-angle thrust faults. A belt of thrusts and high-angle faults extends nearly the entire length of the Sangre de Cristo Mountains, from a few miles south of Salida almost to Santa $\mathrm{Fe}$ on the south. This thrust belt formed on the east side of the San Luis highland. Some of the thrusts are magnificently exposed in Pennsylvanian and Permian rocks in the northern half of the range. Immediately north of the Great Sand Dunes, thrusts have carried Precambrian gneiss over Paleozoic limestone and sandstone. These thrusts are exposed in "windows" where streams have cut down to expose younger rocks below. In the window north of the Sand Dunes, shown in the cross section (fig. 7C), as much as 2 miles of Pennsylvanian sedimentary rocks have been removed by thrust faults, and the thrust itself has been folded and faulted as the upper plate continued to move. A second window is exposed along the trail to Mosca Pass immediately east of the Sand Dunes (see map, fig. 3), and a third small window is exposed high in the range east of Blanca Peak. Rocks, which in Pennsylvanian time lapped onto the late Paleozoic Uncompahgre uplift, lie on rocks that were deposited many miles to the east in the central Colorado trough.

\footnotetext{
*Here are two versions. At the time of his death in the 1700s, while looking up at the red mountains at sunset, the priest Francisco Torres is said to have whispered the words "Sangre de Cristo." A second story: in 1719, after seeing the snowy red mountains at sunrise, the explorer Antonio Valverde y Cosio named the mountains "Sangre de Cristo."
} 
As thrust plates piled up on the east side of the San Luis highland, their weight depressed the west side of the Raton Basin. The basin began to sink and fill with sediment brought by rivers from the highland. Erosion and thrusting proceeded together. Along the west side of the Raton Basin, newly deposited sediment-exposed now as sandstone in Huerfano Park-was uplifted and eroded. Streams inundated the basin with coarse sand and gravel, and coal swamps formed along the shoreline of the great inland sea that lay to the east. These coal deposits were mined for steelmaking at Pueblo, for generating electricity, and for heating thousands of homes. Today they are the source of natural gas for home heating.

Figure 7. The Laramide orogeny. Photographs of folded and faulted rocks of Pennsylvanian and Permian age: $(A)$ folded and overturned Minturn Formation $(\mathrm{Pm})$ overlies upturned beds of Sangre de Cristo Formation (PPs) along the Spread Eagle Peak thrust fault (SEPT) on Mt. Marcy; teeth on upthrown side of thrusts; photograph by S. Soulliere Johnson; $(B)$ the Gibson Peak syncline, a large fold in the Sangre de Cristo Formation northeast of Crestone. (C) Section showing thrust-faulted structure of the Sangre de Cristo Range north of the Great Sand Dunes (see line "A-B" on fig. 3), based on interpretation of surface geology by Lindsey, Johnson, and others (1986). Erosion has exposed a window into rocks beneath a thrust fault that underlies most of the range; gneiss and granite west of Marble Mountain have been thrust over Paleozoic rocks; more faults may underlie the main thrust, but queries (?) emphasize that the deep structure cannot be known without drilling or geophysical surveys.
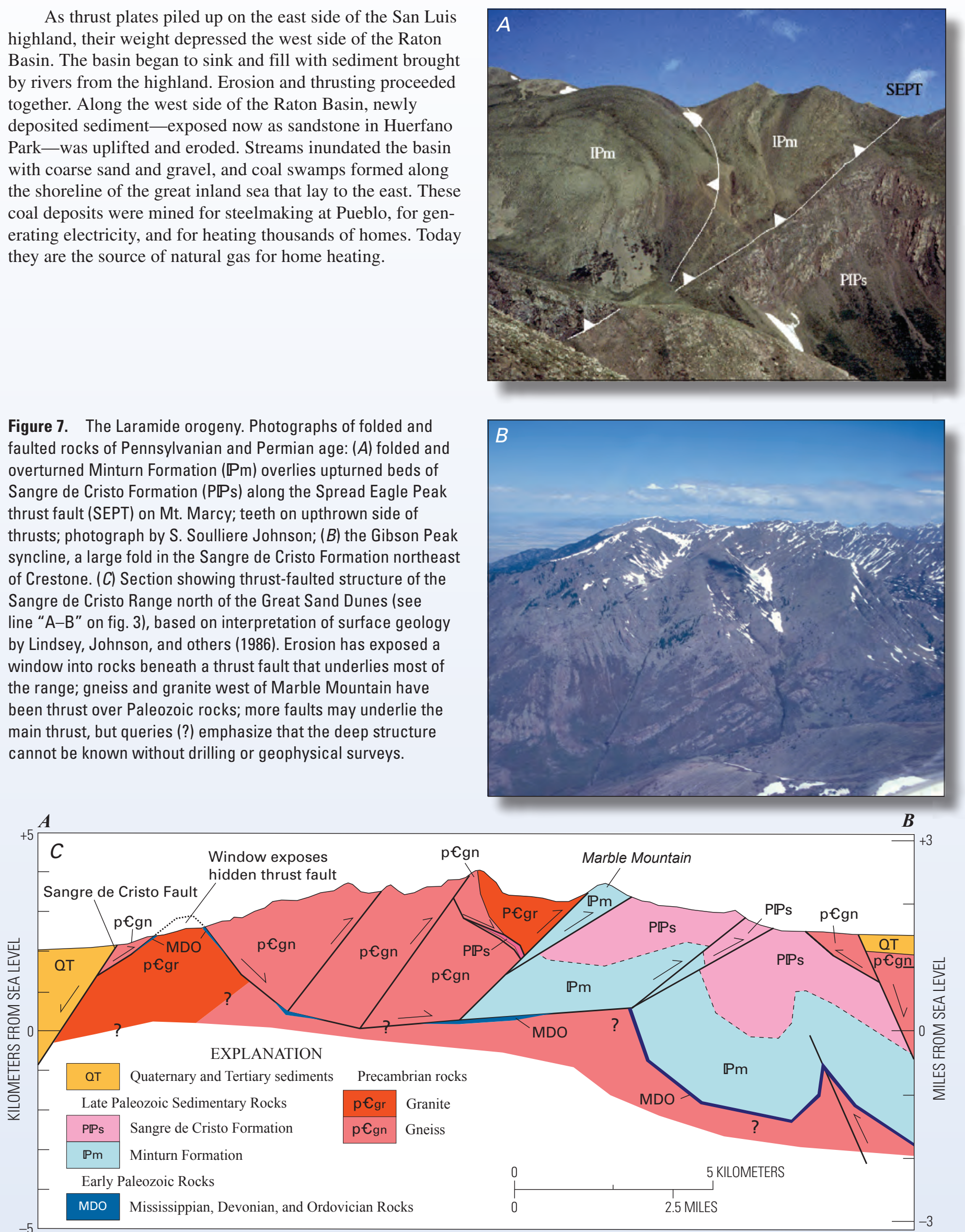

0

0 


\section{The Rio Grande Rift}

The Rio Grande rift fundamentally changed the geology of southern Colorado. About 35-27 million years ago, before the rift (a type of fault valley) formed, volcanoes in the San Juan Mountains and in the Bonanza area west of Villa Grove erupted volcanic ash over the entire landscape. Much of the ash has been eroded, but it is still found in old valleys dating from that time. One of these ancient valleys (called "paleovalleys") has been mapped on the east side of the range northwest of Westcliffe, where a stream crossed the area of the present Sangre de Cristo Range more than 30 million years ago. Ash formations also have been found in boreholes, drilled to explore for oil in the San Luis Valley. These ash beds were deposited before rifting.

About 26 million years ago, in what is now New Mexico and Colorado, the Earth's crust began to pull apart. Why rifting happens is not fully understood, but during rifting heat and molten rock rise from the mantle, uplifting and stretching the Earth's crust. Rifting is always accompanied by block-faulting and volcanic eruptions. The Sangre de Cristo Range contains many small intrusions of igneous rocks dating from the time of rifting or slightly before. The nearby Spanish Peaks is famous for igneous dikes, many of which radiate from central intrusions of igneous rock.

The San Luis and Wet Mountain Valleys began to drop down as the Earth's crust arched upward, stretched, and collapsed. Today the Sangre de Cristo Range stands as a remnant of this uplift. The Wet Mountain Valley has faults on both sides, but the San Luis Valley has only one faulted boundary on the east, the Sangre de Cristo fault (figs. 8A, B). At most places, the fault actually consists of several branches. One branch follows the range front and dips west into the valley at about 60 degrees. At about 10 miles deep, the fault zone probably flattens; at this depth, rocks that are brittle at the surface begin to flow like putty. Geophysical surveys reveal that more than 3 miles of sediment fills the valley on the downthrown side of the fault beneath the Great Sand Dunes. Down-faulting has tilted the lowest fill toward the range, but the upper layers are still horizontal, indicating that the fill was deposited during — not before-rifting.

Fission-track studies of apatite (calcium phosphate-our bones and teeth are made of a variant of this mineral), a trace mineral found in most rocks, show that rifting was especially rapid about 20-12 million years ago. During that time uplift and erosion removed much of the rock cover from the range; the remaining rocks cooled, fission tracks began to form, and the radiometric clock began ticking. Fission tracks are defects left in crystals when uranium atoms split apart. Fission tracks form in proportion to the amount of uranium originally present and, for apatite, the time since the mineral cooled below about $100^{\circ} \mathrm{C}$. They have been used extensively to study the history of uplift and rifting along the Rio Grande Valley.

The range rose again during the last million years or so. Alluvial fans and fault scarps that encircle the southwest sides of Blanca Peak and Twin Peaks record rapid uplift there (fig. 8A, C). If you look closely at the mountain front south of the Great Sand Dunes, you will see fault offsets in alluvium that formed only a few thousand years ago. North of the Great Sand Dunes, many more scarps are apparent along the range front. Large flatiron-shaped features called "faceted spurs" cut off the ridgelines along the Sangre de Cristo fault (fig. 8D). The best time for viewing fault scarps is in the morning or evening, when the low sun angle casts long shadows.

Rift faulting often forms closed basins with no throughgoing drainage, and the Rio Grande Valley was no exception. Eventually the Rio Grande cut through bedrock to connect these basins into a single drainage. The San Luis Valley was still closed about a half million years ago and, during rainy periods, a lake occupied the valley north and east of Alamosa. Sediments and shoreline features from Lake Alamosa are still preserved in a few places southeast of the city. Then the Rio Grande cut through volcanic rock that separated the lake from basins to the south, and the lake drained. Perhaps at this time and later, during the ice ages, strong winds swept over the dry lake basin, picking up the dust and sand that formed the Great Sand Dunes.

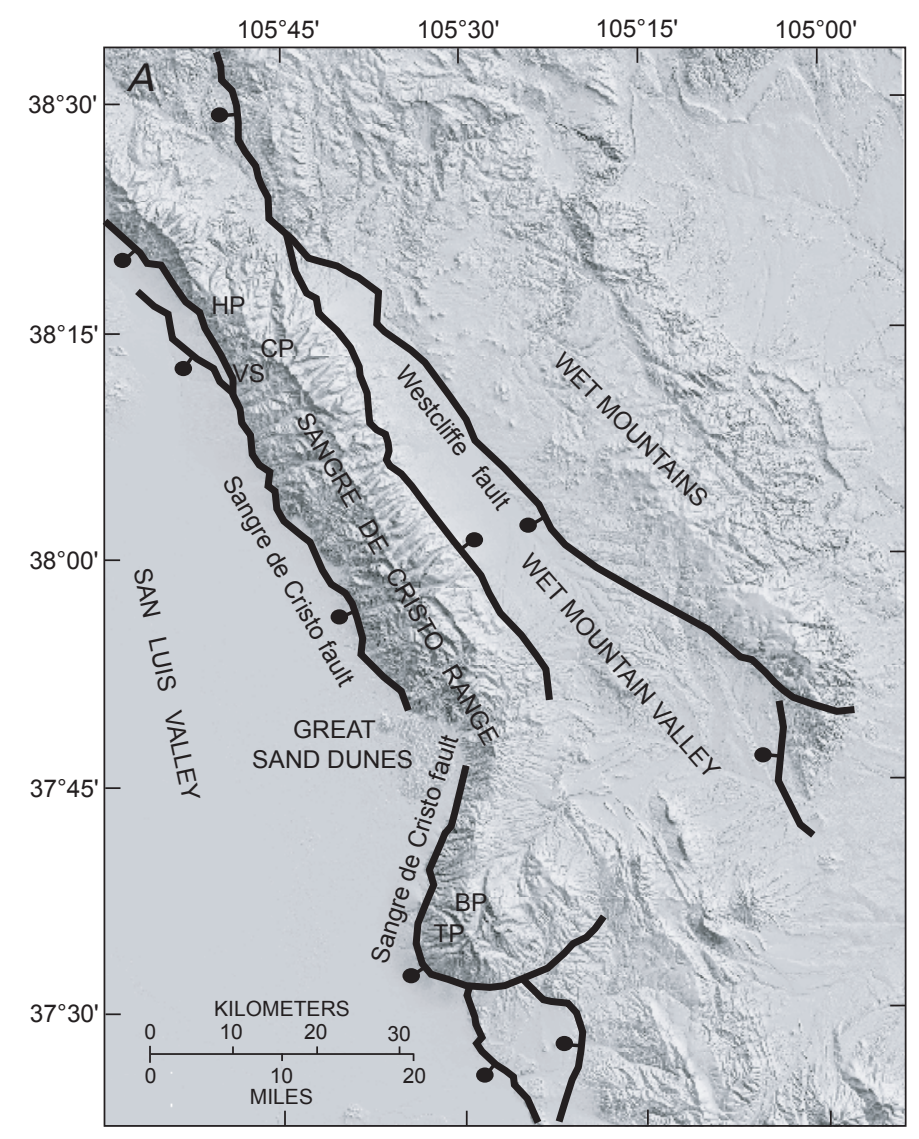

Figure 8 (pages 10 and 11). The Rio Grande rift. $(A)$ Map showing major faults and topographic expression of the Rio Grande rift in the vicinity of the Sangre de Cristo Range. BP, Blanca Peak; $C P$, Cottonwood Peak; HP, Hayden Pass; TP, Twin Peaks; and VS, Valley View Hot Springs. Photographs showing the Sangre de Cristo fault in the San Luis Valley: $(B)$ Looking north at fault scarps (f) and alluvial fans near Valley View Hot Springs (VS). 


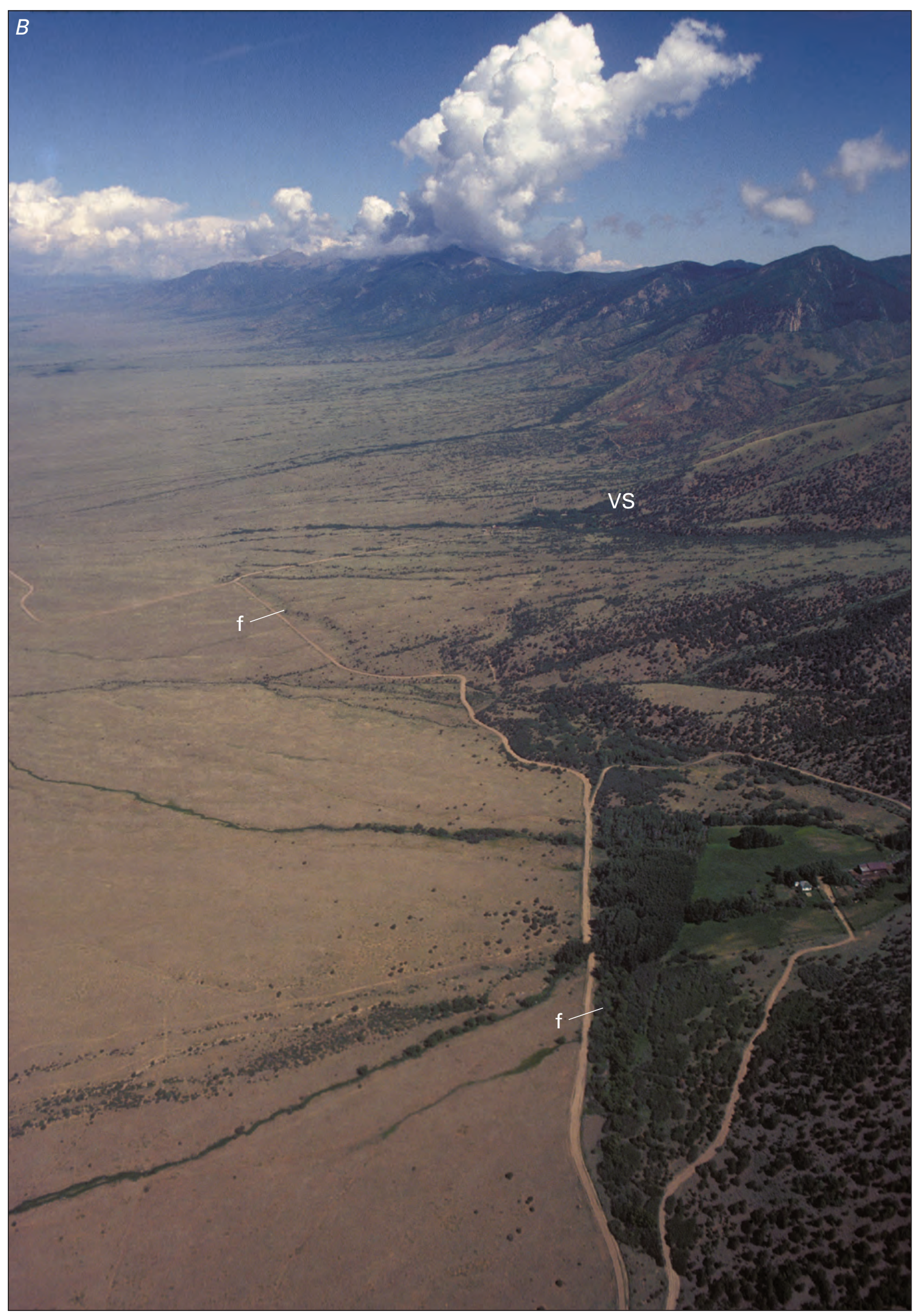



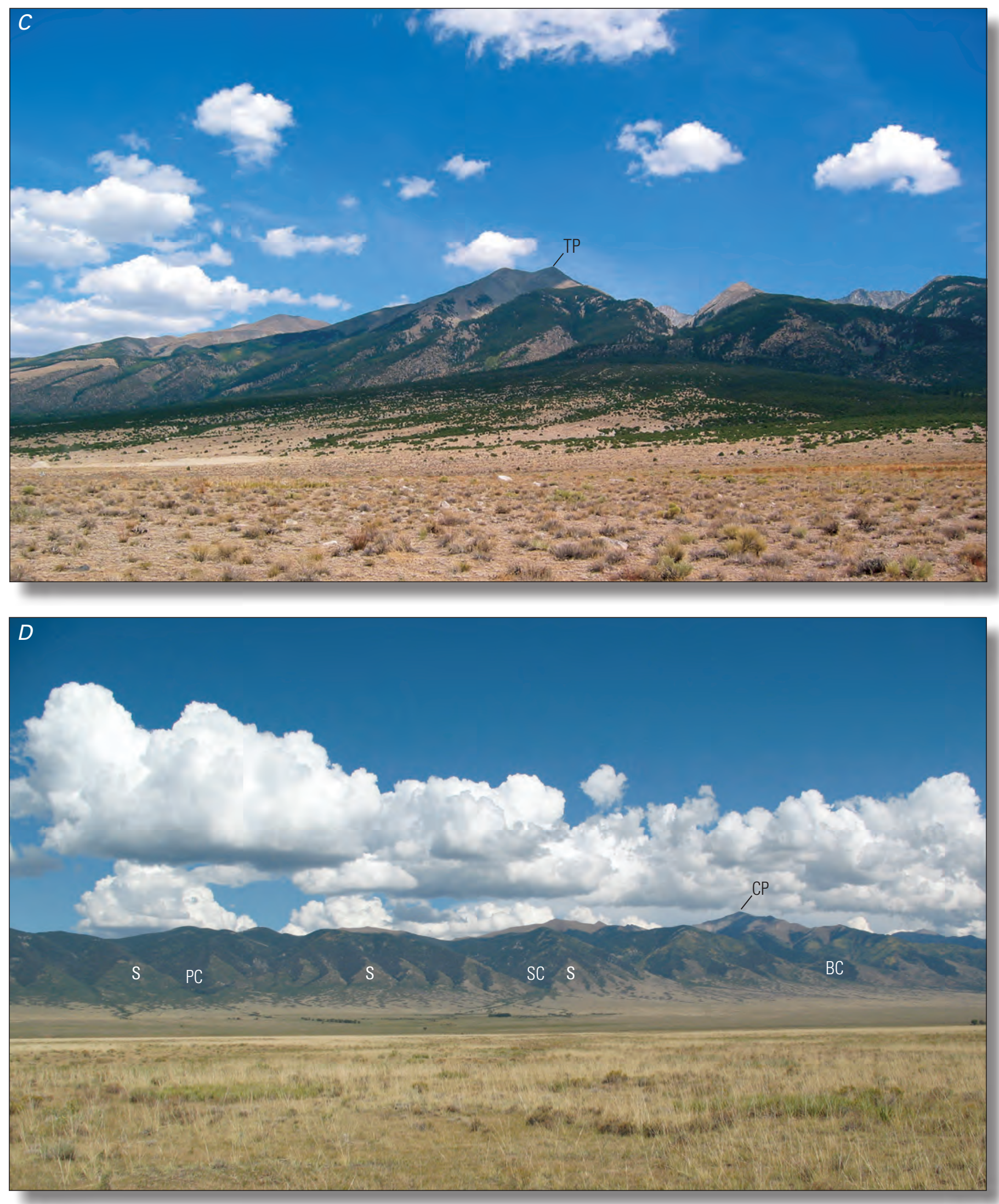

Figure 8 (continued). (C) Alluvial fan south of the Great Sand Dunes, formed during uplift of mountains around Twin Peaks (TP). The Sangre de Cristo fault runs along the foot of the range. $(D)$ Faceted spurs (S, triangular slopes at ends of ridges) and alluvial fans along the fault between Hayden Pass and Valley View Hot Springs. Piney Creek (PC), Steele Canyon (SC), Black Canyon (BC), and Cottonwood Peak (CP). 


\section{The Ice Ages}

The rugged scenery of the Sangre de Cristo Range owes much to erosion by glaciers. Jagged glacier-carved ridges divide the range. Large rock basins called "cirques" occupy the heads of glaciated valleys. Glaciers sculpted the sharp hornshaped summits of Blanca and the Crestones, and scoured rock basin lakes in the valleys below. Along the range front, meltwater streams deposited fans of gravel and sand. Around the southern and western sides of Blanca Peak, fan surfaces are steep and fan gravel accumulated to great thicknesses as faulting continued to down-drop the San Luis Valley (fig. 8C).

Glacial valleys have a characteristic U-shaped cross section. The bedrock in glacial valleys displays grooves and scratch-marks where the ice has dragged embedded stones over it. Such valleys always contain scattered deposits of poorly sorted boulders and clay (called "glacial till"). Glacial landforms composed of till are called "moraines." At their downstream ends, valley glaciers deposit natural dams of till called "terminal moraines." Upstream, wherever the ice front pauses, they deposit still more till dams, called "recessional moraines." On valley walls, steps where ice has rubbed against the bedrock and till has accumulated ("lateral moraines") mark the former height of glacial ice (fig. 9). Meanwhile, back downstream at the ice front, meltwater streams emerge from the glacier and rework the moraine, forming a gravel deposit called an "outwash fan." Almost every glaciated valley in the Sangre de Cristo Range has such an outwash fan.

Valley glaciers formed repeatedly in the Rocky Mountains during the last 1.8 million years; this time is known as the Pleistocene Epoch of the Quaternary Period. Valley glaciers advanced at least three times in the Sangre de Cristo Range. The oldest widespread deposits consist of weathered till and outwash gravel. These deposits, called "Bull Lake" after the type locality in Wyoming, are probably between 190,000 and 130,000 years old. The surface of Bull Lake till is smooth and deposits are deeply weathered to a brown color. Even older (pre-Bull Lake) glacial deposits are known from one place on the east side of the range. About 30,000-12,000 years ago, the last glacial advance scoured the valleys and left fresh deposits of till and outwash. These deposits, called "Pinedale" after another Wyoming locality, form hummocky surfaces and are only weakly weathered. Except for a cover of trees, they look as if they formed yesterday.

Alternating periods of global cooling and warming cause valley glaciers to advance and retreat. During long cool periods - typically hundreds to thousands of years long-snow accumulates year-after-year in high valleys. Accumulation exceeds summer melting and, eventually, the snow becomes ice and flows down the valley under its own weight. As long as the supply of snow and ice exceeds the loss from melting, the front of the glacier advances down the valley, often reaching the foot of the mountains.

Before the industrial age, periods of global cooling and warming were driven by cycles in the Earth's orbit and rotational axis. The Earth's path around the sun varies from nearly circular to elliptical over cycles of about 100,000 and 413,000 years. The tilt of the Earth's axis of rotation changes from $22.1^{\circ}$ to $24.5^{\circ}$ and back every 41,000 years. Finally, the Earth's axis of rotation moves around a pole of the plane defined by the Earth's orbit around the sun every 26,000 years. This rotation, together with the gravitational effects of other planets on the Earth's orbit, produces a 19,000- to 23,000-year cycle called the "precession of the equinoxes." This cycle is so-called because it causes the Earth's equinox to move backward (precess) a few minutes every year. The net result of all these cycles is a complex cooling and warming pattern-called "Milankovitch cycles" after their discoverer-that currently brings a glacial advance about every 100,000 years.

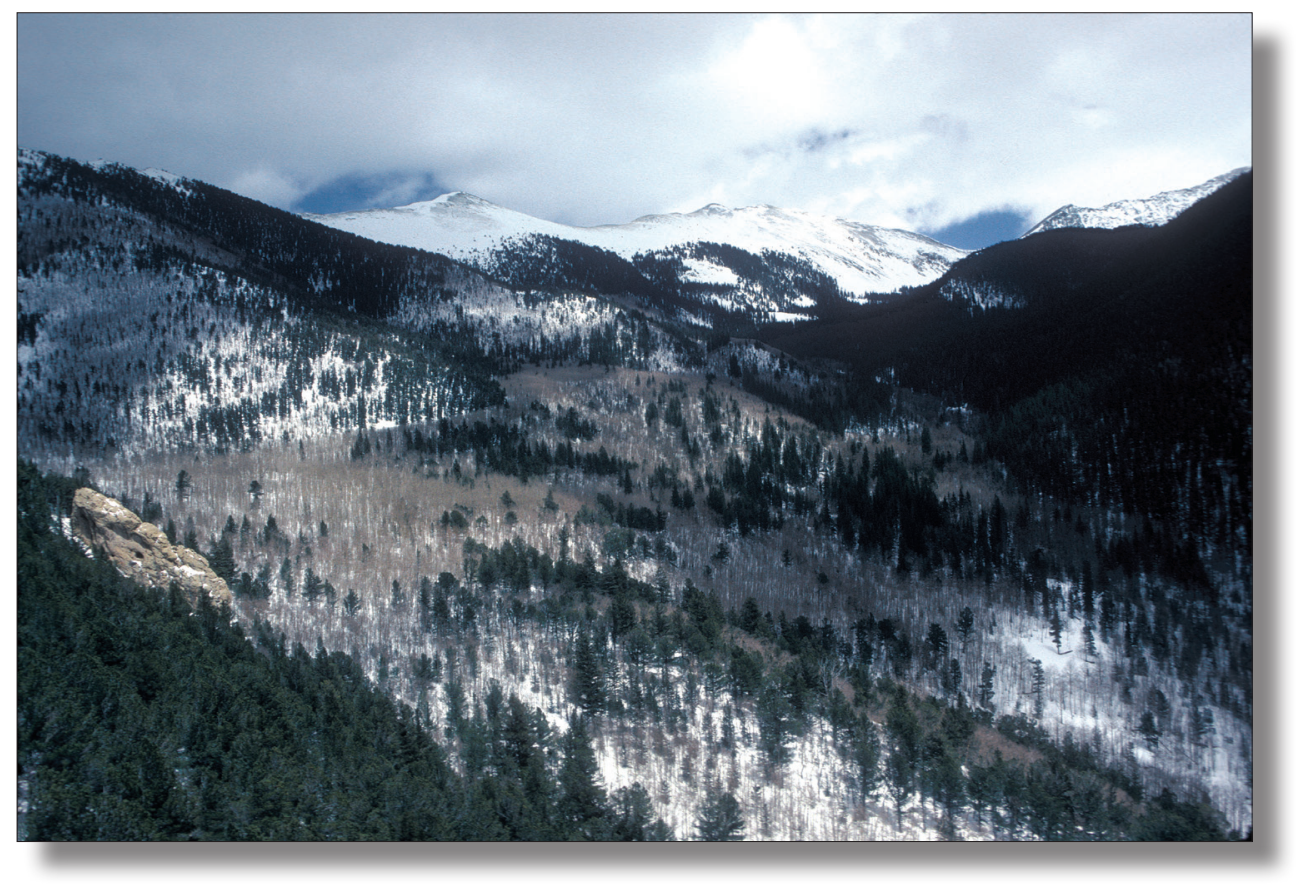

Figure 9. The ice ages. Aspen cover a lateral moraine in Black Canyon, north of Valley View Hot Springs. 


\section{References}

Cather, S.M., McIntosh, W.C., and Kelley, S.A., eds., 2004, Tectonics, geochronology, and volcanism in the Southern Rocky Mountains and Rio Grande rift: New Mexico Bureau of Mines and Mineral Resources Bulletin 160, 317 p.

Ellis, C.E., Hannigan, B.J., and Thompson, J.R., 1983, Mineral investigation of the Sangre de Cristo Wilderness Study Area, Alamosa, Custer, Fremont, Huerfano, and Saguache Counties, Colorado: U.S. Bureau of Mines Open-File Report MLA-65-83, 190 p., 2 plates.

Hoy, R.G., and Ridgway, K.D., 2002, Syndepositional thrustrelated deformation and sedimentation in an Ancestral Rocky Mountains basin, central Colorado trough, Colorado, USA: Geological Society of America Bulletin, v. 114, no. 7, p. 804-828.

Johnson, B.R., Lindsey, D.A., Bruce, R.M., and Soulliere, S.J., 1987, Geologic map of the Sangre de Cristo Wilderness Study Area, Colorado: U.S. Geological Survey Miscellaneous Field Studies Map MF-1635-B, 2 sheets, scale $1: 62,500$.

Jones, J.V., III, and Connelly, J.N., 2006, Proterozoic tectonic evolution of the Sangre de Cristo Mountains, southern Colorado, U.S.A.: Rocky Mountain Geology, v. 41, no. 2, p. 79-116.

Keller, G.R., and Cather, S.M., eds., 1994, Basins of the Rio Grande Rift-Structure, stratigraphy, and tectonic setting: Geological Society of America Special Paper 291, 304 p.

Kelly, S.A., Chapin, C.E., and Corrigan, J., 1992, Late Mesozoic to Cenozoic cooling histories of the flanks of the northern and central Rio Grande Rift, Colorado and New Mexico: New Mexico Bureau of Geology and Mineral Resources Bulletin 145, 39 p.

Kent, H.C., and Porter, K.W., eds., 1980, Colorado geology: Rocky Mountain Association of Geologists, Denver, Colo., $258 \mathrm{p}$.
Lindsey, D.A., Clark, R.F., and Soulliere, S.J., 1986, Minturn and Sangre de Cristo Formations of southern Colorado-A prograding fan-delta and alluvial fan sequence shed from the Ancestral Rocky Mountains, in Peterson, J.A., ed., Paleotectonics and sedimentation: American Association of Petroleum Geologists Memoir 41, p. 541-561.

Lindsey, D.A., Johnson, B.J., and Andriessen, P.A.M., 1983, Laramide and Neogene structure of the Sangre de Cristo Range, south-central Colorado, in Lowell, J.D., ed., Rocky Mountain foreland basins and uplifts: Rocky Mountain Association of Geologists, p. 219-228.

Lindsey, D.A., Johnson, B.R., Soulliere, S.J., Bruce, R.M., and Hafner, K., 1986, Geologic map of the Beck Mountain, Crestone Peak, and Crestone quadrangles, Custer, Huerfano, and Saguache Counties, Colorado: U.S. Geological Survey Miscellaneous Field Studies Map MF-1878, scale 1:24,000.

McCalpin, J.P., 1982, Quaternary geology and neotectonics of the west flank of the northern Sangre de Cristo Mountains, south-central Colorado: Colorado School of Mines Quarterly, v. 77, no. 3, 97 p.

Pierce, K.L., 2003, Pleistocene glaciations of the Rocky Mountains, in Gillespie, A.R., Porter, S.C., and Atwater, B.F., eds., The Quaternary Period in the United StatesDevelopments in Quaternary science, v. 1: Amsterdam, Elsevier, p. 63-76.

Scott, G.R., and Taylor, R.B., 1975, Post-Paleocene Tertiary rocks and Quaternary volcanic ash of the Wet Mountain Valley, Colorado: U.S. Geological Survey Professional Paper 868, 15 p.

U.S. Geological Survey Geologic Names Committee, 2007, Divisions of geologic time-Major chronostratigraphic and geochronologic units: U.S. Geological Survey Fact Sheet 2007-3015, 2 p.

\section{Acknowledgments}

Photograph of Mt. Marcy by S. Soulliere Johnson; geologic map by T. Klein, E. DeWitt, and C. San Juan; reviewed by D.H. Knepper, Jr., and T. Klein; edited by Jon Raese; graphic design and layout by Mari L. Kauffmann (Contractor, ATA Services). Work supported by Bradley Scholar Program grant to D.A. Lindsey. 


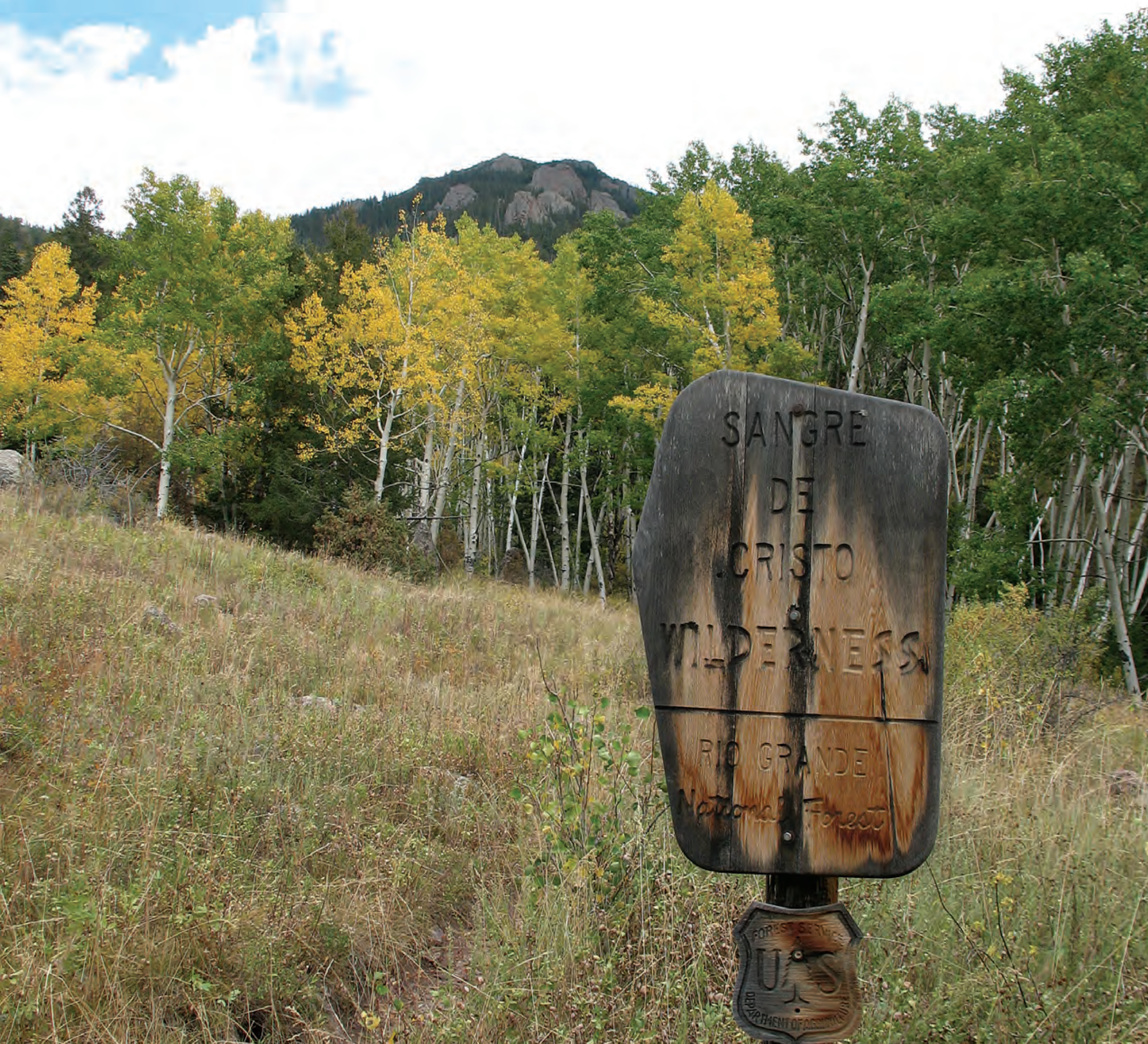

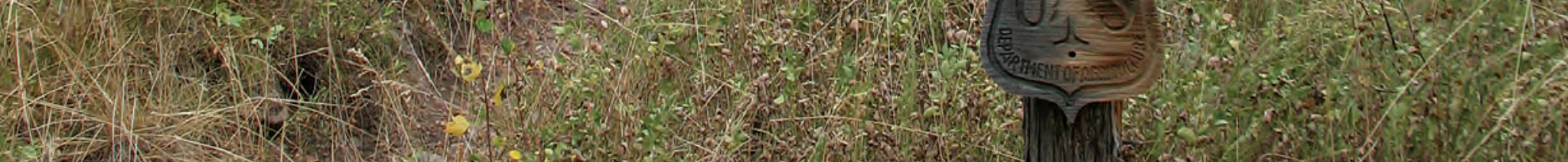
1. (N) 

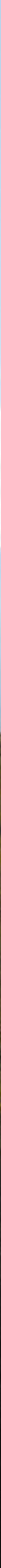
Publishing support provided by:

Denver Publishing Service Center

For more information concerning this publication, contact: Team Chief Scientist, USGS Central Mineral Resources

Box 25046, Mail Stop 973

Denver, CO 80225

(303) 236-1562

Or visit the Central Mineral Resources Team Web site at: http://minerals.cr.usgs.gov/ 


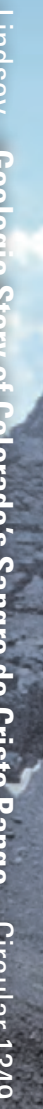

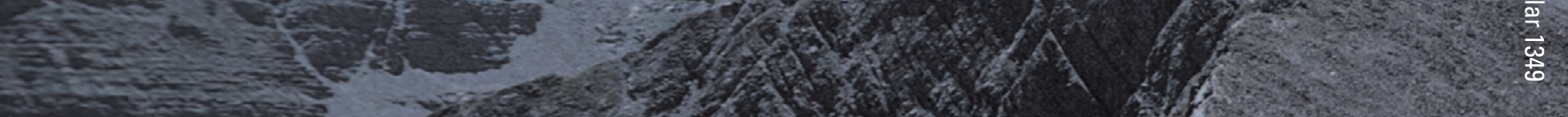

